Article

\title{
Market Volatility and Investors' View of Firm-Level Risk: A Case of Green Firms
}

\author{
Khine Kyaw
}

NTNU Business School, Norwegian University of Science and Technology, Klaebuvein 72, 7030 Trondheim, Norway; khine.kyaw@ntnu.no; Tel.: +47-7312614

Received: 29 June 2020; Accepted: 3 August 2020; Published: 6 August 2020

\begin{abstract}
Do investors believe that firm-level (i.e., idiosyncratic) risk of green (i.e., environmentally responsible) firms is relatively lower? How does high market volatility affect the investors' view on the firm-level risk of green firms? This paper addresses these questions by investigating the relationship between firm-level (idiosyncratic) risk and firms' environmental performance. Further, we examine the effect market volatility has on the relationship. We estimate fixed-effect panel models using 8036 firm-year observations across 793 firms. We test robustness of the results with difference-in-difference (DiD), propensity score matching (PSM) and dynamic panel with the generalized method of moments (GMM) estimations. We find that investors generally associate firms that perform well on the environmental front to be of lower risk. However, during periods of high market volatility, just performing better than the industry does not make the investors see the firms' risk as being significantly lower. How well the firms perform in relation to the industry performance is associated with the investors believing that the firm's risk is significantly lower.
\end{abstract}

Keywords: market volatility; idiosyncratic volatility; environmental performance; environmental responsibility; dynamic panel—system GMM estimations; difference-in-difference; propensity score matching

\section{Introduction}

Stock price reflects the risk of the firms in the eyes of the investors. Economic theories predict that to the extent that firm-level (idiosyncratic) risk is diversifiable, investors are not compensated for carrying firm-level risk. However, Merton (1987) suggests that investors holding imperfectly diversified portfolios should be compensated for carrying firm-level risk. Supporting this suggestion, studies have shown that when investors are not able to diversify the risk, they demand a premium for holding stocks with high firm-level risk (Lintner 1965; Malkiel and Xu 2002; Jones and Rhodes-Kropf 2003) - i.e., higher expected return or lower price. Those studies indicate that firm-level risk is a relevant risk factor with price and return implications for investors.

Green firms behave responsibly towards the environment. Flammer (2013) and Klassen and McLaughlin (1996), among others, have found that firms that perform well on the environmental front enjoy financial benefits and a significant stock price increase. Economic theories predict that 'green-ness' is a resource; thus, engaging in environmental responsibility generates new resources that give firms a competitive-edge (Flammer 2013). Studies have shown that green firms experience higher stock price as the investors see 'green-ness' as value enhancing. However, relatively little is known about how the investors view the risk of green firms. We attempt to address this issue in this paper.

A survey by Accenture and United Nations Global Compact (UNGC) (Accenture, and UNGC 2010) shows that 93 percent of 766 CEOs believe that sustainability will be critical to the future success of their business. Instrumental stakeholder theory by Jones (1995) claimed that addressing stakeholders' environmental interests is critical in acquiring resources or stakeholder support, which in turn can 
improve the firms' reputation and appeal to stakeholders who are concerned about the environment. Similarly, Porter (1991) posited that the classic goals of firms such as profitability, and environmental responsibility such as pollution reduction are not necessarily mutually exclusive goals. He claimed that efforts to reduce pollution such as improved products or production processes can strengthen firms competitiveness while reducing the firms' environmental footprints. Studies on waste management (Russo and Harrison 2005) and environmental management systems (Melnyk et al. 2003) find that firms can become sustainable through environmentally responsible business actions. Moreover, addressing environmental issues ameliorates the probabilities of expected environmental crisis that could influence adversely firms' cash flows (Sharfman and Fernando 2008), or generates intangible assets such as goodwill or reputation that help preserve firms' financial performance (Godfrey et al. 2009). Jo and $\mathrm{Na}$ (2012) found that firm total risk as measured by the market beta is negatively related to firms' corporate social responsibility (CSR) activities. A more recent literature identified CSR activities as strategically chosen approaches to exploit the opportunities presented at points of intersection between a firm and society (Jo and Na 2012; Porter and Kramer 2011). Jo and Na (2012) claim that firms addressing the opportunities related to those intersection points can potentially present risk-reducing actions that are unique for their customers, that consequently increase the market appeal to the customers. Furthermore, CSR engagements have shown to ease access to financial markets and thus financial constraints (Cheng et al. 2011). In sum, environmentally responsible behaviors can make the firms sustainable while endowing the firms with additional resources and competitive advantage. Consequently, profits environmentally friendly firms generate should be sustainable. Therefore, the investors may believe that environmentally responsible firms have relatively low firm-level risk.

The resources and competitive advantage firms have generated through environmentally responsible behaviors will become valuable during periods of high market uncertainty. At times of high market uncertainty, investors face difficulty forecasting future earnings of firms (Choi 2018). For environmentally responsible firms, the sustainable profits generated through the resources and competitive advantage should make the task of forecasting relatively easier for the investors. Cheema-Fox et al. (2020) showed that firms that commit to their stakeholder relations such as environmental preservations provide a signal of resilience to investors. Consequently, they experience less negative stock returns during market collapses. Thus, in the investors' view, environmentally responsible firms will have a relatively low firm-level risk at times of high market uncertainty.

Through fixed-effect panel estimation of 8036 firm-year observations, we find that investors believe firm-level risk to be lower in firms that behave responsibly towards the environment. Although firm-level risk tends to be lower for firms that perform better than the industry, firm-level risk is significantly lower only for firms that perform well above the industry-wide performance. At times of high market volatility, behaving responsibly towards the environment is not enough to make investors believe that firm-level risk is significantly low. During those periods, firms need to perform better than the industry-wide performance level to make the investors believe that their relative firm-level risk is significantly low.

Findings in this paper have several contributions to the literature. First, they contribute to a better understanding of green firms. Literature on green firms so far have shown that environmentally friendly corporate strategies are valued positively by the investors (Flammer 2013). We contribute to the literature by showing that addressing the environment can lower the firm-level risk as perceived by the investors. This finding has implications for firms' stock price and cost of capital. Second, the results also show the importance of addressing environmental performance in relation to the industry-wide performance level in order that investors see the firm-level risk to be significantly low. This finding has implications for corporate decision makings and strategy formulations. Third, this study links firm-level risk (i.e., idiosyncratic risk) to firms' performance on the environmental front. The literature on idiosyncratic risk has mainly focused on the effect it has on stock returns, but relatively little is known about the sources of idiosyncratic risk. Findings in this study shed more lights on this. 
The next section describes the data and methodology. Section 3 presents results, and Section 4 concludes.

\section{Data and Methodology}

Environmental performance, governance and the remaining data on U.S. firms for the period from 2002 to 2018 are collected from Thomson Reuters Refinitiv. The database collects environment and governance data on firms in major indexes-in particular, S\&P 500, NASDAQ 100 and Russell 1000. The market is defined as all the securities in CRSP database. We require that the data on shareholder's equity, total assets, trading volume and market capitalization be non-negative, and that all variables of interest are available to be included in the sample. Application of the criteria yields a total of 8036 firm-year observations, i.e., unbalanced panel data on 793 firms.

\subsection{Firm-Level Risk as Assessed by the Investors}

Idiosyncratic volatility (ivol) indicates the firm-level risk resulting from the investors' assessment of the firms' risk. ivol is monthly idiosyncratic volatility, multiplied by 12, estimated from Fama-French three-factor model. The model is estimated using a 12-month estimation window, with a minimum of 10 months of available data.

\subsection{Green Firms}

Green firms behave responsibly towards the environment. This is achieved through the resources used, recycling programs, emissions, and so on. Thus, we capture firms' 'green-ness' by their performance in terms of addressing the environment as indicated by Refinitiv's environment score. We construct three measures of environmental performance.

The first measure of environmental performance is Refinitiv's environment score (env). It captures the general performance of the firms towards the environment. Refinitiv's environment score is the weighted average relative rating of a company based on the reported environmental information. With considerations around comparability, data availability, and industry relevance, Thomson Reuters Refinitiv captures and calculates scores on resource use, emissions and innovation. Resource use category score reflects a company's performance and capacity to reduce the use of materials, energy or water, and to find more eco-efficient solutions by improving supply chain management. Emission category score measures a company's commitment and effectiveness towards reducing environmental emission in the production and operational processes. Environmental innovation category score reflects a company's capacity to reduce the environmental costs and burdens for its customers, and thereby creating new market opportunities through new environmental technologies and processes or eco-designed products. Environmental score ranges from 0 to 1 , one being the best performance score.

We construct two additional measures based on the general environmental performance measure. env1 is an indicator variable that takes a value of one if a firms' env is above industry-year specific median-env or is otherwise zero This variable captures the relative environmental performance of the firms. In addition to this, we construct env2 which is a variable that takes the value of env if firms' env is above industry-year specific median-env or is otherwise zero. The variable captures the level of relative environmental performance of the firms.

\subsection{High Market Volatility}

To investigate the effect high market uncertainty has on the investors' assessment of the firm-level risk of green firms, we identify periods of high market volatility based on CBOE VIX index. The index provides a gauge of the market's anticipated uncertainty. The higher the index, the higher the market's anticipated uncertainty. We define high volatility periods as the years where the standard deviation of daily-VIX for the year is higher than the median standard-deviation-of-daily-VIX in the most recent five years. This approach identifies years 2002-2003, 2007-2009, 2011, 2015-2016, and 2018 as high 
volatility periods. Figure 1 plots the dynamics of VIX index. The grayed periods represent the periods of high market volatility.

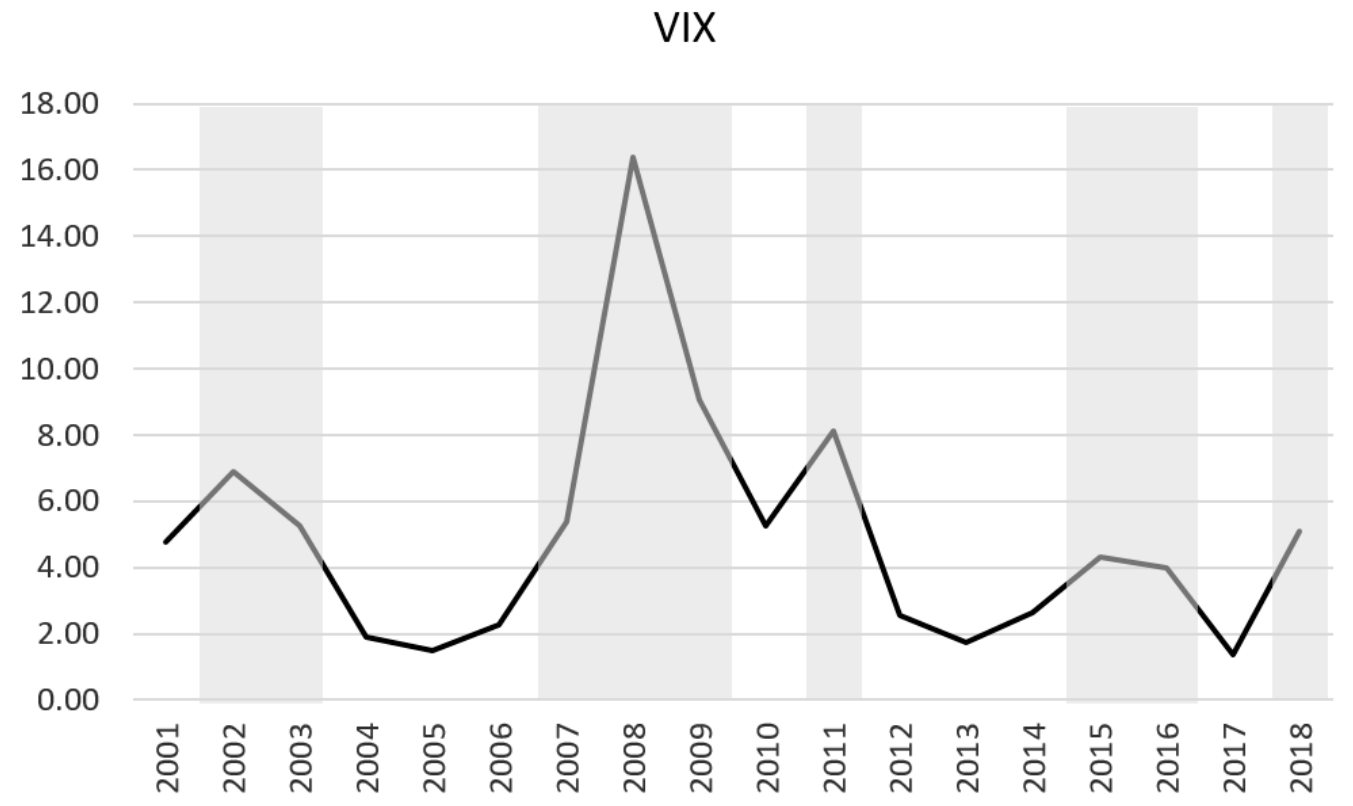

Figure 1. Time series of VIX index.

\subsection{Controls}

The investors' belief about the firm-level risk can be influenced by the firms' governance. Thus, we control for the firms' performance in terms of governance. Refinitiv's governance score is the weighted average relative rating of a company based on the reported governance information and the resulting three governance category scores: (1) management category score measures a company's commitment and effectiveness towards following best practice corporate governance principles, (2) shareholders category score measures a company's effectiveness towards equal treatment of shareholders and the use of anti-takeover devices, and (3) CSR strategy category score reflects a company's practices to communicate that it integrates the economic (financial), social and environmental dimensions into its day-to-day decision-making processes.

We control for factors that can affect firm-level risk and subsequently the investors' assessment of the risk. For this purpose, we control for firms' risk taking (risktaking) measured as the standard deviation of the firms' adjusted return on assets, following John et al. (2008) and Langenmayr and Lester (2018). If a firm assumes more risk, it can affect the investors' view of the firm-level risk; also included as controls are: profitability (return on equity, roe), as it can affect firms' ability to undertake risky projects, and growth opportunities (market-to-book ratio, $m k t 2 b o o k$ ), as it can influence the amount of risk firms need to undertake. Further, we control for risk associated with cash flows generated from operating (cashflow), firm-level risk attributable to financial distress (leverage), firm age (age) and industry (industry). Since larger firms tend to have lower overall operating risk (John et al. 2008), we control for firm size (size). Finally, market microstructure such as the stocks' liquidity can influence the investors' perception of the firm-level risk (Kyaw 2006; Chan et al. 2013). Therefore, we control for stock liquidity as proxied by trading volume (volume). Appendix A describes definition of the variables.

Table 1 provides an overview of the variables. The mean idiosyncratic risk is 0.057 with a maximum of 0.646 . The values are much lower than the mean and maximum idiosyncratic risk of 0.194 and 2.471, respectively, reported by Ferreira and Laux (2007). This is because firms in our sample are relatively large firms with low idiosyncratic risk. Refinitiv covers firms in major indexes such as S\&P500 and NASDAQ100, while Ferreira and Laux (2007) studied all the available stocks in the 
CRSP database. The average environmental score is 0.302 with some of the firms in the sample not engaging in activities targeted towards the environment as indicated by the minimum environmental score of zero. All the firms in the sample have some degree of good governance practices while the wide range of governance scores (from 0.003 to 0.985 ) indicates that some firms excel in adopting good governance measures.

Table 1. Descriptive statistics.

\begin{tabular}{ccccccc}
\hline Variable & Mean & sd & p50 & Min & Max & N \\
\hline ivol & 0.057 & 0.033 & 0.048 & 0.010 & 0.646 & 8036 \\
env & 0.302 & 0.286 & 0.235 & 0.000 & 0.985 & 8036 \\
cg & 0.519 & 0.226 & 0.530 & 0.003 & 0.985 & 8036 \\
size & 15.995 & 1.335 & 15.861 & 11.778 & 21.392 & 8036 \\
leverage & 0.237 & 0.186 & 0.199 & 0.000 & 0.986 & 8036 \\
roe & 0.166 & 0.449 & 0.128 & -12.337 & 19.681 & 8036 \\
mkt2book & 3.758 & 7.044 & 2.431 & 0.344 & 231.952 & 8036 \\
age & 3.969 & 1.762 & 3.434 & 0.000 & 7.610 & 8036 \\
risktaking & 0.024 & 0.041 & 0.011 & 0.000 & 0.652 & 8036 \\
cashflow & 0.106 & 0.075 & 0.097 & -0.498 & 0.852 & 8036 \\
volume & 22.754 & 1.124 & 22.720 & 18.335 & 26.805 & 8036 \\
\hline
\end{tabular}

This table reports descriptive statistics on the variables. Appendix A describes all variables.

Table 2 shows pair-wise correlations between the variables. Firms' idiosyncratic risk is negatively associated with environmental score and governance score. Larger, older, and more profitable firms tend to have lower idiosyncratic risk. However, firms with higher risk taking and higher leverage have higher idiosyncratic risk.

Table 2. Correlation.

\begin{tabular}{ccccccccccc}
\hline & Ivol & Env & $\mathrm{Cg}$ & Size & Leverage & Roe & Mkt2book & Age & Risktaking & Cashflow \\
\hline ivol & 1 & & & & & & & & & \\
env & $\mathbf{- 0 . 1 4 6 0}$ & 1 & & & & & & & & \\
cg & $\mathbf{- 0 . 1 3 7 3}$ & $\mathbf{0 . 4 9 3 8}$ & 1 & & & & & & & \\
size & $\mathbf{- 0 . 2 5 3 3}$ & $\mathbf{0 . 3 6 1 5}$ & $\mathbf{0 . 3 3 5 1}$ & 1 & & & & & & \\
leverage & $\mathbf{0 . 1 1 9 4}$ & $\mathbf{0 . 0 2 5 4}$ & $\mathbf{0 . 0 6 1 3}$ & $\mathbf{0 . 3 4 3 7}$ & 1 & & & & \\
roe & $\mathbf{- 0 . 1 0 9 3}$ & $\mathbf{0 . 0 8 7 3}$ & $\mathbf{0 . 0 7 1 8}$ & -0.0119 & $\mathbf{- 0 . 1 3 9 1}$ & 1 & & & \\
mkt2book & $\mathbf{- 0 . 0 4 7 4}$ & $\mathbf{0 . 0 6 6 0}$ & $\mathbf{0 . 0 3 0 7}$ & $\mathbf{- 0 . 0 9 0 4}$ & $\mathbf{- 0 . 1 7 5 2}$ & $\mathbf{0 . 7 1 0 6}$ & 1 & & \\
age & $\mathbf{- 0 . 0 3 6 4}$ & $\mathbf{0 . 1 0 4 9}$ & $\mathbf{0 . 1 1 7 5}$ & 0.0066 & $\mathbf{- 0 . 0 6 1 1}$ & 0.0163 & $\mathbf{0 . 0 2 2 5}$ & 1 & & \\
risktaking & $\mathbf{0 . 2 6 9 3}$ & $\mathbf{- 0 . 0 4 0 9}$ & $\mathbf{- 0 . 0 4 5 8}$ & $\mathbf{- 0 . 1 5 1 3}$ & $\mathbf{- 0 . 0 2 4 1}$ & $\mathbf{- 0 . 0 6 5 5}$ & -0.0038 & 0.0106 & 1 & \\
cashflow & -0.015 & $\mathbf{0 . 0 4 5 5}$ & -0.0017 & $\mathbf{- 0 . 3 4 8 6}$ & $\mathbf{- 0 . 4 7 1 5}$ & $\mathbf{0 . 2 4 4 9}$ & $\mathbf{0 . 2 1 7 1}$ & $\mathbf{0 . 0 6 1 0}$ & $\mathbf{0 . 0 5 3 9}$ & 1 \\
volume & $\mathbf{0 . 0 8 8 4}$ & $\mathbf{0 . 3 7 5 4}$ & $\mathbf{0 . 3 0 4 1}$ & $\mathbf{0 . 4 9 8 1}$ & $\mathbf{0 . 1 0 2 1}$ & 0.017 & $\mathbf{0 . 0 2 7 7}$ & $\mathbf{0 . 1 2 3 8}$ & $\mathbf{0 . 1 2 6 7}$ & $\mathbf{0 . 0 3 1 9}$ \\
\hline
\end{tabular}

The table reports pairwise correlation between the variables. Appendix A describes all variables. Bold indicates significance at $5 \%$ level.

\subsection{Model}

We estimate fixed-effect (FE) panel model of the following form.

$$
\text { ivol }_{i t}=\beta e n v_{\text {pperformance }}{ }_{i t}+\boldsymbol{x}^{\prime}{ }_{i t} \gamma+v_{i}+\varepsilon_{i t} \quad i=1, \ldots, N ; t=1, \ldots, T
$$

where $i v o l_{i t}$ represents idiosyncratic volatility for firm $i$ at time $t . \mathbf{x}_{i t}$ is a vector of controls, $v_{i}$ denotes an unobservable time-constant firm-level fixed effect, $\varepsilon_{i t}$ is an error term. $\beta$ and $\gamma$ are the coefficient and the vector of coefficients estimated.

We first estimate Equation (1) for the whole sample. Then we re-estimate Equation (1) for periods of high market volatility. We do this exercise for each of the three measures of environmental performance score. 


\section{Results}

Models (1), (2), and (3) in Table 3 report the estimation results from Equation (1) for the whole sample period from 2002 through 2018. After controlling for firm characteristics that can affect the investors' perception of firm-level risk, we find that environmental performance measures have a negative coefficient; thus, the investors perceive that firm-level risk is on average lower in firms with better environmental performance. The negative and statistically significant coefficient of -0.0067 for env suggests that an improvement in firms' environmental performance score by one unit is associated with the investors believing that firm-level risk is reduced by 0.0067 units on average. There is a considerable variation in the environmental performance across industries (Jo and Na 2012). Models (2) and (3) employ firms' environmental performance in relation to the industry they belong to. We employ two relative performance measures: (1) whether a firm performs better than the industry (env1), and (2) the extent to which a firm performs better than the industry (env2). The coefficient estimate for env1 in Model (2) suggests that performing better than the industry tends to be associated with the investors viewing firm-level risk to be relatively lower; but, it is not significantly lower. However, better level of environmental performance than the industry (env2) is associated with significantly lower firm-level risk as viewed by the investors. These results complement findings by Jo and Na (2012) that CSR is negatively related to firms' total and market risks. The results here show that the investors believe firm-specific risk to be relatively low in firms that perform well on the environmental front. Re-estimation of (1), (2), and (3) for high volatility period yields Models (4), (5) and (6), respectively. During high volatility periods, better environmental performance (env) tends to be associated with the investors' viewing the firm-level risk as relatively lower, but not significantly lower as indicated by the coefficient estimate for env of -0.0059 . The statistically significant coefficient values for env1 and env2 of -0.0022 and -0.0045 suggest that striving to do better than the industry during high volatility periods is associated with the investors believing that the firm-level risk is significantly reduced. Table 3 also shows that investors' perceive better governed firms to have relatively lower firm-level risk. This is consistent with the findings by Bernile et al. (2018), and Pathan (2009) that better governed firms tend to have relatively lower firm risk. Bernile et al. (2018) explains that better governed firms are able to adopt more persistent and less risky financial policies. Our results suggest that this is reflected in the investors' perception of the firms' risk. Moreover, investors perceive firms that can generate higher profit and have more liquid stocks to be less risky (Mathew et al. 2017). Similar to Bernile et al. (2018) and Jo and $\mathrm{Na}$ (2012), we find that the investors' perception of firm-level risk is lower for older and larger firms. Moreover, investors perceive highly leveraged firms, and firms with high risk taking to have high firm-level risk.

Table 3. Fixed-effect panel regression.

\begin{tabular}{|c|c|c|c|c|c|c|}
\hline & \multicolumn{3}{|c|}{ Whole Period } & \multicolumn{3}{|c|}{ High Volatility Period } \\
\hline & (1) & (2) & (3) & (4) & (5) & (6) \\
\hline env & $\begin{array}{c}-0.00667^{* *} \\
(0.00331)\end{array}$ & & & $\begin{array}{l}-0.00590 \\
(0.00516)\end{array}$ & & \\
\hline env1 & & $\begin{array}{l}-0.000983 \\
(0.000862)\end{array}$ & & & $\begin{array}{c}-0.00223 * \\
(0.00121)\end{array}$ & \\
\hline env2 & & & $\begin{array}{c}-0.00311^{*} \\
(0.00186)\end{array}$ & & & $\begin{array}{c}-0.00452 * \\
(0.00262)\end{array}$ \\
\hline $\mathrm{cg}$ & $\begin{array}{c}-0.00666^{* *} \\
(0.00272)\end{array}$ & $\begin{array}{c}-0.00754^{* * *} \\
(0.00278)\end{array}$ & $\begin{array}{c}-0.00733^{* * * *} \\
(0.00275)\end{array}$ & $\begin{array}{c}-0.00924 \text { ** } \\
(0.00418)\end{array}$ & $\begin{array}{c}-0.00978^{* *} \\
(0.00438)\end{array}$ & $\begin{array}{c}-0.00965 * * \\
(0.00430)\end{array}$ \\
\hline size & $\begin{array}{c}-0.00703^{* * *} \\
(0.00128)\end{array}$ & $\begin{array}{c}-0.00725^{* * *} \\
(0.00125)\end{array}$ & $\begin{array}{c}-0.00720^{* * *} \\
(0.00126)\end{array}$ & $\begin{array}{c}-0.00568 * * * \\
(0.00176)\end{array}$ & $\begin{array}{c}-0.00580^{* * *} \\
(0.00169)\end{array}$ & $\begin{array}{c}-0.00579 * * * \\
(0.00171)\end{array}$ \\
\hline leverage & $\begin{array}{c}0.0563 * * * \\
(0.00562)\end{array}$ & $\begin{array}{c}0.0564 * * * \\
(0.00564)\end{array}$ & $\begin{array}{c}0.0564^{* * *} \\
(0.00563)\end{array}$ & $\begin{array}{l}0.0500^{* * *} \\
(0.00637)\end{array}$ & $\begin{array}{l}0.0502 * * * \\
(0.00637)\end{array}$ & $\begin{array}{l}0.0501 * * * \\
(0.00636)\end{array}$ \\
\hline roe & $\begin{array}{l}-0.00199 * \\
(0.00107)\end{array}$ & $\begin{array}{c}-0.00192 * \\
(0.00105)\end{array}$ & $\begin{array}{c}-0.00194^{*} \\
(0.00106)\end{array}$ & $\begin{array}{c}-0.00526^{* *} \\
(0.00261)\end{array}$ & $\begin{array}{c}-0.00507^{*} \\
(0.00261)\end{array}$ & $\begin{array}{c}-0.00508^{*} \\
(0.00263)\end{array}$ \\
\hline
\end{tabular}


Table 3. Cont.

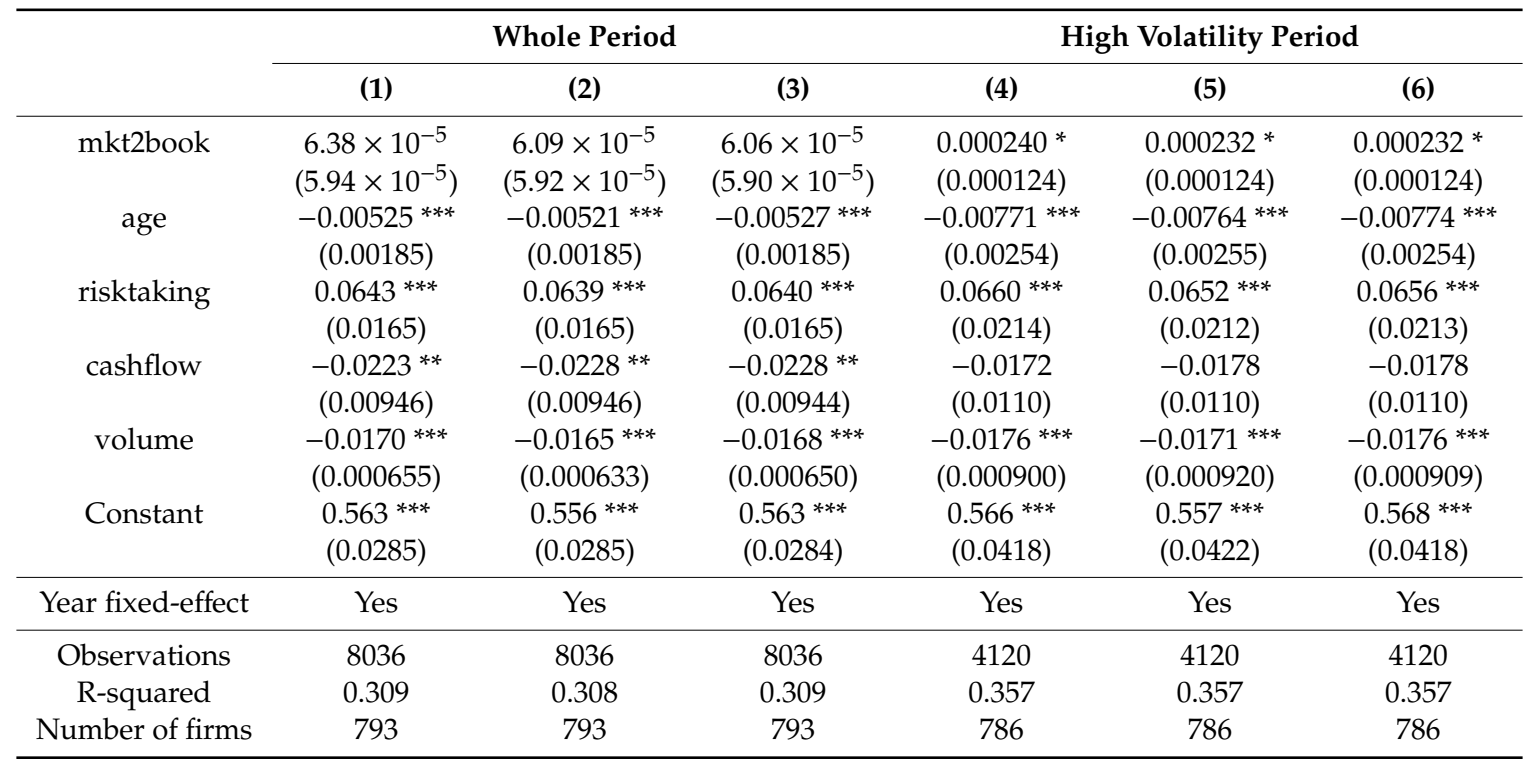

This table reports estimation results from fixed-effect panel estimation. env captures the general performance of the firms towards the environment. env1 is an indicator variable that takes a value one if firms' env is above industry-year specific median-env, or zero otherwise. env2 takes the value of env if firms' env is above industry-year specific median-env, or zero otherwise. Control variables are as follows: $c g$ to capture the general governance of firms, risktaking (the standard deviation of the firms' adjusted return on assets) for firms' risk taking, roe (return on equity) for profitability, mkt2book (market-to-book ratio) for growth opportunities, cashflow for cash flow generated from operations, volume for stock liquidity, leverage for financial risk, age for firm age, and size for firm size. Appendix A provides detailed descriptions of the variables. Models (1), (2) and (3) are estimated on the whole sample period from 2002 to 2018. Models (4), (5) and (6) are estimated on high volatility periods. Market uncertainty is measured by VIX index. High volatility period is defined as the year where the standard deviation of daily-VIX for the year is higher than the median standard-deviation-of-daily-VIX in the most recent five years. This approach identifies years 2002-2003, 2007-2009, 2011, 2015-2016, and 2018 as high volatility periods. Robust standard errors are in parentheses. ${ }^{*}, * * * *$ represent significance at $10 \%, 5 \%$ and $1 \%$, respectively.

\subsection{Robustness Tests}

\subsubsection{Difference-in-Difference (DiD)}

To understand the effect high market volatility has on the relationship between environmental performance and the investors' assessment of firm-level risk, we estimate DiD equation as represented in Equation (2).

$$
\begin{aligned}
& \text { ivol }_{i t}=\beta_{1} \text { env_performance } i t+\beta_{2} \text { high_vix }_{t}+\beta_{3} \text { env_performance }{ }_{i t} \mathrm{x} \text { high_VIX }+x_{t}^{\prime}{ }_{i t} \gamma+v_{i}+\varepsilon_{i t} \\
& i=1, \ldots, N ; t=1, \ldots, T
\end{aligned}
$$

The variable of interest is the coefficient $\beta_{3}$ which shows the relationship between environmental performance during high market volatility periods and the investors' assessment of firm-level risk. Table 4 shows that $\beta_{3}$ is negative but not significant for all three models. Model (1) shows that although environmental performance is associated with lower firm-level risk in the eyes of the investors (as indicated by the negative and statistically significant coefficient for env), firm-level risk is relatively high under high market volatility (as indicated by the positive and statistically significant coefficient for high_vix). The net effect of the two effects $\left(e n v \times h i g h \_v i x\right)$ resulted in a relatively low, but not significantly lower, firm-level risk for firms with better environmental performance during periods of high market volatility. Similarly, Models (2) and (3) show that performing better than the industry-performance-level tends to be associated with the investors seeing firm-level risk to be relatively low (as shown by the sign for the coefficients for variables env1 $\mathrm{x}$ high_vix, and env2 $\times$ high_vix. However, statistical insignificance of the coefficients suggest that the investors do not seem to think that firm-level risk is significantly lower for firms that perform better than the industry-performance-level 
than the rest firms. Similar to the findings from Table 3, Table 4 shows that investors perceive firms that are older, have good governance, and can generate cash flow to have relatively low firm-level risk. In addition, the investors see firms that have actively traded stock have low firm-level risk. Moreover, investors' perception of firm-level risk is positively related to firms' risk taking and financial risk level.

Table 4. Difference-in-difference.

\begin{tabular}{|c|c|c|c|}
\hline & (1) & (2) & (3) \\
\hline env & $\begin{array}{c}-0.00656^{* *} \\
(0.00334)\end{array}$ & & \\
\hline env1 & & $\begin{array}{l}-0.000706 \\
(0.000900)\end{array}$ & \\
\hline env2 & & & $\begin{array}{l}-0.00285 \\
(0.00200)\end{array}$ \\
\hline high_vix & $\begin{array}{c}0.00450 * * \\
(0.00225)\end{array}$ & $\begin{array}{c}0.00268 \\
(0.00195)\end{array}$ & $\begin{array}{c}0.00302 \\
(0.00197)\end{array}$ \\
\hline env $\times$ high_vix & $\begin{array}{c}-0.000192 \\
(0.00169)\end{array}$ & & \\
\hline env1 $\times$ high_vix & & $\begin{array}{l}-0.000531 \\
(0.000845)\end{array}$ & \\
\hline env2 $\times$ high_vix & & & $\begin{array}{c}-0.000468 \\
(0.00155)\end{array}$ \\
\hline $\mathrm{cg}$ & $\begin{array}{c}-0.00666^{* *} \\
(0.00273)\end{array}$ & $\begin{array}{c}-0.00753^{* * *} \\
(0.00278)\end{array}$ & $\begin{array}{c}-0.00734^{* * *} \\
(0.00276)\end{array}$ \\
\hline size & $\begin{array}{c}-0.00703 * * * \\
(0.00128)\end{array}$ & $\begin{array}{c}-0.00725^{* * *} \\
(0.00125)\end{array}$ & $\begin{array}{c}-0.00720 * * * \\
(0.00126)\end{array}$ \\
\hline leverage & $\begin{array}{l}0.0563 * * * \\
(0.00561)\end{array}$ & $\begin{array}{l}0.0564 * * * \\
(0.00564)\end{array}$ & $\begin{array}{l}0.0564 * * * \\
(0.00563)\end{array}$ \\
\hline roe & $\begin{array}{c}-0.00199 * \\
(0.00107)\end{array}$ & $\begin{array}{c}-0.00191 * \\
(0.00105)\end{array}$ & $\begin{array}{c}-0.00193 * \\
(0.00105)\end{array}$ \\
\hline mkt2book & $\begin{array}{r}6.37 \times 10^{-5} \\
\left(5.95 \times 10^{-5}\right) \\
\end{array}$ & $\begin{array}{r}6.11 \times 10^{-5} \\
\left(5.92 \times 10^{-5}\right) \\
\end{array}$ & $\begin{array}{r}6.06 \times 10^{-5} \\
\left(5.90 \times 10^{-5}\right) \\
\end{array}$ \\
\hline age & $\begin{array}{c}-0.00525^{* * *} \\
(0.00185)\end{array}$ & $\begin{array}{c}-0.00520^{* * *} \\
(0.00185)\end{array}$ & $\begin{array}{c}-0.00526^{* * *} \\
(0.00185)\end{array}$ \\
\hline risktaking & $\begin{array}{c}0.0643^{* * *} \\
(0.0165)\end{array}$ & $\begin{array}{c}0.0639^{* * *} \\
(0.0165)\end{array}$ & $\begin{array}{c}0.0640^{* * *} \\
(0.0165)\end{array}$ \\
\hline cashflow & $\begin{array}{c}-0.0223 * * \\
(0.00946)\end{array}$ & $\begin{array}{l}-0.0228 * * \\
(0.00945)\end{array}$ & $\begin{array}{c}-0.0228^{* *} \\
(0.00944)\end{array}$ \\
\hline volume & $\begin{array}{l}-0.0170 * * * \\
(0.000668)\end{array}$ & $\begin{array}{c}-0.0166^{* * *} \\
(0.000636)\end{array}$ & $\begin{array}{l}-0.0169 * * * \\
(0.000665)\end{array}$ \\
\hline Constant & $\begin{array}{l}0.564 * * * \\
(0.0283)\end{array}$ & $\begin{array}{l}0.558^{* * * *} \\
(0.0285)\end{array}$ & $\begin{array}{l}0.565^{* * *} \\
(0.0281)\end{array}$ \\
\hline Year effect & Yes & Yes & Yes \\
\hline Observations & 8036 & 8036 & 8036 \\
\hline R-squared & 0.309 & 0.308 & 0.309 \\
\hline Number of firms & 793 & 793 & 793 \\
\hline
\end{tabular}

This table presents results of the difference-in-differences analysis estimated using FE-panel estimation. env captures the general performance of the firms towards the environment. env1 is an indicator variable that takes a value one if firms' env is above industry-year specific median-env, or zero otherwise. env2 takes the value of env if firms' env is above industry-year specific median-env, or zero otherwise. Control variables are as follows: $c g$ to capture the general governance of firms, risktaking (the standard deviation of the firms' adjusted return on assets) for firms' risk taking, roe (return on equity) for profitability, mkt2book (market-to-book ratio) for growth opportunities, cashflow for cash flow generated from operations, volume for stock liquidity, leverage for financial risk, age for firm age, and size for firm size. Robust standard errors are in parentheses. ${ }^{*},{ }^{* *},{ }^{* * *}$ represent significance at $10 \%, 5 \%$ and $1 \%$, respectively. Appendix A provides detailed description of all variables. 


\subsubsection{Propensity Score Matching (PSM)}

Like any study in this field, there are some potential endogeneity issues in the study. First, we cannot ascertain if the causation is actually reverse: that firms of a certain firm-level risk drive environmental performance given the benefits such behavior can bring. To address them we conduct PSM analysis for the whole sample period as well as high market volatility period. We construct a control group based on firms' propensity score (pscore) estimated using probit regression below.

$$
\begin{aligned}
\text { pscore }_{i t}= & \alpha_{0}+\alpha_{1} \text { cg g }_{i t}+\alpha_{2} \text { size }_{i t}+\alpha_{3} \text { leverage }_{i t}+\alpha_{4} \text { roe }_{i t}+\alpha_{5} \text { mkt } 2 \text { book }_{i t}+\alpha_{6} \text { age }_{i t}+\alpha_{7} \text { risktaking }_{i t} \\
& +\alpha_{8} \text { cashflow }_{i t}+\alpha_{9} \text { volume }_{i t}+\sum \alpha_{j} \text { Year }_{\text {dummy }}+\sum \pi_{k} \text { Industry }_{\text {dummy }}+\varepsilon_{i t} .
\end{aligned}
$$

Panel A in Table 5 reports the results from the estimation of Equation (3). Treatment effect of environmental performance on firm-level risk as perceived by the investors is estimated using treatment effect on the treated (ATT) approach. The treated group represents the firms whose environmental performance score is above industry-year specific median-environmental-performance score. The control group represents the firms that are similar in size, leverage, roe, market2book, age, risktaking, cashflow, volume, year and industry, except that their environmental performance score is below industry-year specific median-environmental-performance score. Matching is done with replacement. Results in Panel B of Table 5 show that for the whole sample period the difference between the treated and the control groups is -0.00375 . This confirms the earlier observations from Table 3: the investors see firm-level risk as lower in firms that perform well on environmental front. However, during highly volatile periods, doing well on the environmental front is not associated with the investors believing the firms represent a significantly low risk, as indicated by the difference between the treated and the control groups of -0.00171 . This is different from the results reported in Model (5) of Table 3 in that the coefficient for env1 is significant at the $10 \%$ level.

\begin{tabular}{|c|c|c|}
\hline \multicolumn{3}{|c|}{ Panel A: Probit Estimation Result for Propensity Score } \\
\hline & Whole & High Volatility \\
\hline $\mathrm{cg}$ & $\begin{array}{c}1.28904^{* * *} \\
(0.09499)\end{array}$ & $\begin{array}{c}1.31063^{* * *} \\
(0.13327)\end{array}$ \\
\hline size & $\begin{array}{c}0.53312 * * * \\
(0.02611)\end{array}$ & $\begin{array}{c}0.51380 * * * \\
(0.03654)\end{array}$ \\
\hline leverage & $\begin{array}{c}-0.82716^{* * *} \\
(0.13980)\end{array}$ & $\begin{array}{c}-0.69752 * * * \\
(0.18229)\end{array}$ \\
\hline roe & $\begin{array}{c}0.04784 \\
(0.05872)\end{array}$ & $\begin{array}{c}0.02032 \\
(0.06969)\end{array}$ \\
\hline mkt2book & $\begin{array}{l}-0.00179 \\
(0.00426)\end{array}$ & $\begin{array}{c}0.00276 \\
(0.00619)\end{array}$ \\
\hline age & $\begin{array}{c}0.01604 \\
(0.01128)\end{array}$ & $\begin{array}{c}0.01857 \\
(0.01572)\end{array}$ \\
\hline risktaking & $\begin{array}{l}-0.20839 \\
(0.49759)\end{array}$ & $\begin{array}{l}-0.29795 \\
(0.67082)\end{array}$ \\
\hline cashflow & $\begin{array}{c}0.99748^{* * * *} \\
(0.33422)\end{array}$ & $\begin{array}{c}1.27275^{* * *} \\
(0.45978)\end{array}$ \\
\hline volume & $\begin{array}{c}0.20936^{* * *} \\
(0.02724)\end{array}$ & $\begin{array}{c}0.21808^{* * *} \\
(0.03807)\end{array}$ \\
\hline _cons & $\begin{array}{c}-14.40691 * * * \\
(0.72157)\end{array}$ & $\begin{array}{c}-14.29582 * * * \\
(0.91561)\end{array}$ \\
\hline Year effect & Yes & Yes \\
\hline Industry effect & Yes & Yes \\
\hline observations & 7888 & 3987 \\
\hline Pseudo R2 & 0.2195 & 0.212 \\
\hline
\end{tabular}

Table 5. Propensity score matching. 
Table 5. Cont.

\begin{tabular}{ccc}
\hline Panel B: Treatment Effect of Environmental Performance on ivol \\
\hline Unmatched & & \\
Treated & 0.05313 & 0.05638 \\
Controls & 0.05941 & 0.06340 \\
Difference & $-0.00628^{* * *}$ & $-0.00702^{* * *}$ \\
& $(0.00074)$ & $(0.00117)$ \\
ATT & & \\
Treated & 0.05313 & 0.05638 \\
Controls & 0.05670 & 0.05810 \\
Difference & $-0.00357^{* *}$ & -0.00171 \\
& $(0.00137)$ & $(0.00216)$
\end{tabular}

\begin{abstract}
Idiosyncratic volatility of firms with high environmental performance-treated group-is compared to idiosyncratic volatility of firms with low environmental performance-control group. The control group is chosen based on firms' propensity score (pscore) estimated using probit regression: pscore $_{i t}=\alpha_{0}+\alpha_{1}$ cg $_{i t}+\alpha_{2}$ size $_{i t}+\alpha_{3}$ leverage $_{i t}+$

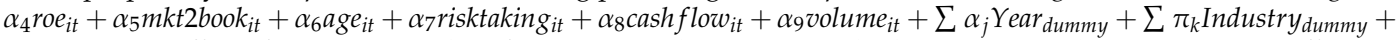
$\varepsilon_{i t}$. Treatment effect of environmental performance on idiosyncratic volatility is estimated using treatment effect on the treated (ATT) approach. The control group represent nearest neighbors chosen with replacement. cg captures the general governance of firms, risktaking (the standard deviation of the firms' adjusted return on assets) captures firms' risk taking, roe (return on equity) captures firms' profitability, mkt2book (market-to-book ratio) captures growth opportunities, cashflow indicates cash flow generated from operations, volume measures stock liquidity, leverage indicates financial risk, age is firm age, and size is firm size. Standard errors are in parentheses. ${ }^{* *},{ }^{* * *}$ represent significance at $10 \%, 5 \%$ and $1 \%$, respectively. Appendix A describes in details all variables.
\end{abstract}

\title{
3.1.3. Dynamic Panel Estimation-GMM Approach
}

To address potential endogeneity differently, we estimate dynamic fixed-effects model using system GMM approach on the matched sample (i.e., treated and control group together), matched through pscore. ${ }^{1}$ In addition to simultaneity, there also is a possibility that environmental performance is merely a symptom of an underlying unobservable factor that also affects firm-level risk (i.e., unobservable heterogeneity). A dynamic panel-system GMM model enables us to estimate the relationship between firm-level risk and environmental performance while including both past firm-level risk and fixed-effects to account for, respectively, the dynamic aspects of the relationship and time-invariant unobservable heterogeneity. By incorporating the dynamic nature of the environmental performance, system GMM provides valid and powerful instruments that address unobserved heterogeneity and simultaneity (Wintoki et al. 2012). Table 6 summarizes the results from the dynamic panel estimations. The coefficients of lagged ivol indicate that past firm-level risk explains the variation in current firm-level risk. Coefficients of environmental performance measures (i.e., env, env1, and env2) from the table supports findings from Tables 3 and 4. (1) In general, the investors see firms with high environmental performance to have lower firm-level risk. (2) However, during periods of high market volatility, simply doing better than the industry is not sufficient (as indicated by the coefficient for env1) to make investors believe that firm-level risk is lower. (3) The investors believe that only those firms that do better than the industry in absolute terms have lower firm-level risk. AR(2) second-order serial correlation test yields z-values that do not reject the null. This means that we cannot reject the null hypothesis of no second-order serial correlation. Except for high volatility sub-period analyses, the Hansen J-statistic on over-identifying restrictions has values that do not reject the hypothesis that our instruments are valid. The significantly reduced availability of firm-year observations for the sub-period analysis together with the use of lagged values as instruments in the estimations could have influenced the test statistics for overidentification in Models (4)-(6). The last row in Table 6 reports the results from exogeneity tests. The J-statistic values do not reject the null at the 5 percent level that the instruments that we use in the levels equations are exogenous.

1 We also re-estimate Equation (1) with the matched sample. The results do not change qualitatively and are available upon request. 
Table 6. Dynamic panel estimation (matched sample).

\begin{tabular}{|c|c|c|c|c|c|c|}
\hline & \multicolumn{3}{|c|}{ Whole Period } & \multicolumn{3}{|c|}{ High Volatility } \\
\hline & (1) & (2) & (3) & (4) & (5) & (6) \\
\hline L1.ivol & $\begin{array}{l}0.462 * * * \\
(0.0712)\end{array}$ & $\begin{array}{l}0.474^{* * *} \\
(0.0678)\end{array}$ & $\begin{array}{l}0.472 * * * \\
(0.0689)\end{array}$ & $\begin{array}{l}0.511 * * * \\
(0.0774)\end{array}$ & $\begin{array}{l}0.527 * * * \\
(0.0712)\end{array}$ & $\begin{array}{l}0.515^{* * *} \\
(0.0729)\end{array}$ \\
\hline L2.ivol & $\begin{array}{c}-0.0913 * * \\
(0.0356)\end{array}$ & $\begin{array}{c}-0.0937 * * * \\
(0.0331)\end{array}$ & $\begin{array}{c}-0.0910 * * * \\
(0.0335)\end{array}$ & $\begin{array}{c}-0.148^{* * *} \\
(0.0492)\end{array}$ & $\begin{array}{c}-0.138 * * * \\
(0.0444)\end{array}$ & $\begin{array}{c}-0.141 * * * \\
(0.0458)\end{array}$ \\
\hline env1 & & $\begin{array}{c}-0.00109 \\
(0.000995)\end{array}$ & & & $\begin{array}{c}-0.000721 \\
(0.00178)\end{array}$ & \\
\hline env2 & & & $\begin{array}{l}-0.00310 \\
(0.00225)\end{array}$ & & & $\begin{array}{c}-0.00568 * \\
(0.00328)\end{array}$ \\
\hline leverage & $\begin{array}{l}0.0492 * * * \\
(0.00715)\end{array}$ & $\begin{array}{l}0.0498^{* * *} \\
(0.00728)\end{array}$ & $\begin{array}{l}0.0500 * * * \\
(0.00734)\end{array}$ & $\begin{array}{l}0.0644^{* * *} \\
(0.00846)\end{array}$ & $\begin{array}{l}0.0659^{* * *} \\
(0.00850)\end{array}$ & $\begin{array}{l}0.0641 \text { *** } \\
(0.00823)\end{array}$ \\
\hline roe & $\begin{array}{c}-0.00895^{* * *} \\
(0.00304)\end{array}$ & $\begin{array}{c}-0.00895^{* * *} \\
(0.00307)\end{array}$ & $\begin{array}{c}-0.00917 * * * \\
(0.00312)\end{array}$ & $\begin{array}{c}-0.0116^{* *} \\
(0.00522)\end{array}$ & $\begin{array}{c}-0.0128 * * \\
(0.00506)\end{array}$ & $\begin{array}{l}-0.0121 * * \\
(0.00521)\end{array}$ \\
\hline mkt2book & $\begin{array}{c}0.000336^{* * *} \\
(0.000127)\end{array}$ & $\begin{array}{c}0.000327^{* * *} \\
(0.000126)\end{array}$ & $\begin{array}{c}0.000339^{* * *} \\
(0.000130)\end{array}$ & $\begin{array}{l}0.000394 \text { * } \\
(0.000233)\end{array}$ & $\begin{array}{c}0.000451 \text { ** } \\
(0.000228)\end{array}$ & $\begin{array}{l}0.000409 * \\
(0.000234)\end{array}$ \\
\hline age & $\begin{array}{c}-0.000818 * \\
(0.000447)\end{array}$ & $\begin{array}{c}-0.000869 * * \\
(0.000432)\end{array}$ & $\begin{array}{c}-0.000745 * \\
(0.000441)\end{array}$ & $\begin{array}{c}-0.00133^{* *} \\
(0.000648)\end{array}$ & $\begin{array}{l}-0.00119 * \\
(0.000699)\end{array}$ & $\begin{array}{l}-0.00123 * \\
(0.000632)\end{array}$ \\
\hline Constant & & $\begin{array}{c}0.0610^{* * *} \\
(0.0227)\end{array}$ & $\begin{array}{c}0.0217 \\
(0.0224)\end{array}$ & $\begin{array}{l}0.00361 \\
(0.0573)\end{array}$ & $\begin{array}{c}0.0676 \\
(0.0469)\end{array}$ & $\begin{array}{c}0.0251 \\
(0.0447)\end{array}$ \\
\hline Year effect & Yes & Yes & Yes & Yes & Yes & Yes \\
\hline Observations & 5896 & 5896 & 5896 & 3222 & 3222 & 3222 \\
\hline Number of firms & 759 & 759 & 759 & 752 & 752 & 752 \\
\hline AR(1) test (z-statistic) & $-4.79 * * *$ & $-4.93^{* * *}$ & $-4.90 * * *$ & $-4.89 * * *$ & $-5.06^{* * *}$ & $-5.02 * * *$ \\
\hline AR(2) test (z-statistic) & 0.66 & 0.75 & 0.70 & 0.60 & 0.61 & 0.58 \\
\hline $\begin{array}{c}\text { Hansen test of } \\
\text { over-identification } \\
\text { (J-statistic) }\end{array}$ & 587.52 & 591.09 & 594.34 & $347.99 * * *$ & $347.43^{* * *}$ & $352.08 * * *$ \\
\hline $\begin{array}{l}\text { Diff-in-Hansen tests of } \\
\text { exogeneity (J-statistic) }\end{array}$ & 108.58 & 102.48 & 109.04 & $88.84 *$ & 76.45 & $87.82 *$ \\
\hline
\end{tabular}

Firms are matched based on their propensity score (pscore) estimated
using probit regression: sscore $_{i t}=\alpha_{0}+\alpha_{1}$ cg $_{i t}+\alpha_{2}$ size $_{i t}+\alpha_{3}$ leverage $_{i t}+$

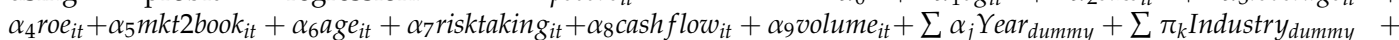
$\varepsilon_{i t}$. Dynamic panel is then estimated on the matched firms using GMM estimation. env captures the general performance of the firms towards the environment. env1 is an indicator variable that takes a value one if firms' env is above industry-year specific median-env, or zero otherwise. env2 takes the value of env if firms' env is above industry-year specific median-env, or zero otherwise. Control variables are as follows: cg to capture the general governance of firms, risktaking (the standard deviation of the firms' adjusted return on assets) for firms' risk taking, roe (return on equity) for profitability, mkt2book (market-to-book ratio) for growth opportunities, cashflow for cash flow generated from operations, volume for stock liquidity, leverage for financial risk, age for firm age, and size for firm size. Robust standard errors are in parentheses. ${ }^{*},{ }^{* *},{ }^{* * *}$ represent significance at $10 \%, 5 \%$ and $1 \%$, respectively. Appendix A describes in details all variables. 


\section{Conclusions}

Do investors believe that firms that do well in terms of their environmental responsibility have relatively lower firm-level risk? We find that the investors tend to believe so. In general, the investors see firms that do better with environmental responsibility and firms whose environmental performance is better in absolute terms than the industry performance level as having significantly low firm-level risk. The investors do not seem to believe that firm-level risk is significantly reduced just because firms' environmental performance is above industry performance level. During periods of high market volatility, the investors believe only those firms that do well beyond the industry performance level have a significantly low firm-level risk. During those periods, although the investors tend to see firms that behave responsibly towards the environment and those that perform better than the industry environmental-performance level to have a relatively low firm-level risk, the risk level is not significantly low.

This study shows that there is a relationship between firms' environmental performance and the investors' believe about firm-specific risk. Future studies could examine any moderating factors that could influence the nature of the relationship. For instance, how does the firms' ability to communicate their environmental engagement activities affect the investors' perception of the firm's risk? Moreover, we have used firm-specific risk component of the firms' total risk implied by the stock returns as an approximation of the investors' perception of firm-level risk. This approach has enabled us to investigate the general belief of the investors about the firms' risk and how market volatility affects the belief in general. However, different types of investors may have different beliefs about the firms' risk. Therefore, future studies could employ survey data to establish whether investors' beliefs about the firms' risk varies across different types of investors.

Funding: This research received no external funding.

Conflicts of Interest: The authors declare no conflict of interest.

\section{Appendix A}

Table A1. Variable Definitions.

\begin{tabular}{|c|c|}
\hline Variable & Definition \\
\hline \multicolumn{2}{|l|}{ Dependent variable } \\
\hline Idiosyncratic volatility $(i v o l)$ & $\begin{array}{l}\text { Monthly idiosyncratic volatility (multiplied by } 12 \text { to annualize) } \\
\text { estimated from Fama-French three-factor model using a } 12 \text {-month } \\
\text { estimation window, with a minimum of } 10 \text { months available data. }\end{array}$ \\
\hline \multicolumn{2}{|l|}{ Independent variable } \\
\hline Environmental performance (env) & $\begin{array}{l}\text { Refinitiv's environment score calculated from resource use, emission, } \\
\text { and environmental innovation information reported. }\end{array}$ \\
\hline Environmental performance 1 (env1) & $\begin{array}{l}\text { Indicator variable that takes a value one if a firm's env is above } \\
\text { industry-year specific median env, or zero otherwise. }\end{array}$ \\
\hline Environmental performance 2 (env2) & $\begin{array}{l}\text { Indicator variable that takes the value of env if a firm's env is above } \\
\text { industry-year specific median ESG_env, or zero otherwise. }\end{array}$ \\
\hline \multicolumn{2}{|r|}{ 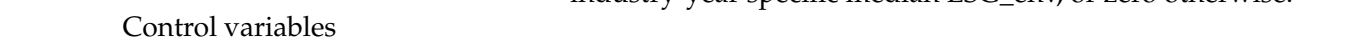 } \\
\hline Corporate governance $(c g)$ & $\begin{array}{l}\text { Refinitiv's governance score calculated from firm's management, } \\
\text { shareholders, and csr strategy. }\end{array}$ \\
\hline Firm size (size) & Natural logarithm of total assets \\
\hline Leverage (leverage) & Total debt/(market value of equity + total debt) \\
\hline Return on equity (roe) & Net income/total shareholders' equity \\
\hline Market-to-book (Mkt2book) & Market capitalization/(total assets - total debt) \\
\hline Firm age (age) & Natural logarithm of firm age \\
\hline Cash flow (cashflow) & Cash flow from operations/total assets \\
\hline Trading volume (volume) & Natural logarithm of trading volume (in 100s) \\
\hline Firm risk taking (risktaking) & $\begin{array}{c}\text { Standard deviation over three years of a firm's return on assets' (roa's) } \\
\text { deviation from the industry-year specific average roa calculated as in } \\
\text { Langenmayr and Lester (2018) }\end{array}$ \\
\hline Industry (industry) & SIC code \\
\hline
\end{tabular}

This table summarizes the definition of the variables used in the analyses. Data on U.S. firms for the period from 2002 to 2018 are collected from Thomson Reuters Refinitiv. 


\section{References}

Accenture, and UNGC. 2010. A New Era of Sustainability: UN Global Compact-Accenture CEO Study 2010. New York: United Nations Global Compact and Accenture.

Bernile, Gennaro, Vineet Bhagwat, and Scott Yonker. 2018. Board diversity, firm risk and corporate policies. Journal of Financial Economics 127: 588-612. [CrossRef]

Chan, Kalok, Allaudeen Hameed, and Wenjin Kang. 2013. Stock price synchronicity and liquidity. Journal of Financial Markets 16: 414-38. [CrossRef]

Cheema-Fox, Alexander, Bridget Realmuto LaPerla, George Serafeim, and Hui Wang. 2020. Corporate Resilience and Response during COVID-19. Havard Business School Working Paper No. 20-108. Boston: Havard Business School.

Cheng, Beiting, Ioannis Ioannou, and George Serafeim. 2011. Corporate social responsibility and access to finance. Strategic Management Journal 35: 1-23.

Choi, Hae Mi. 2018. A tale of two uncertainties. Journal of Banking and Finance 92: 81-99. [CrossRef]

Ferreira, Miguel A., and Paul A. Laux. 2007. Corporate governance, idiosyncratic risk, and information flow. Journal of Finance 62: 951-89. [CrossRef]

Flammer, Caroline. 2013. Corporate social responsibility and shareholder reaction: The environmental awareness of investors. Academy of Management Journal 56: 758-81. [CrossRef]

Godfrey, Paul C., Craig B. Merrill, and Jared M. Hansen. 2009. The relationship between corporate social responsibility and shareholder value: An empirical test of the risk management hypothesis. Strategic Management Journal 30: 425-45. [CrossRef]

Jo, Hoje, and Haejung Na. 2012. Does CSR reduce firm risk? Evidence from controversial industry sectors. Journal of Business Ethics 110: 441-56. [CrossRef]

John, Kose, Lubomir Litov, and Bernard Yeung. 2008. Corporate governance and risk-taking. Journal of Finance 63: 1679-728. [CrossRef]

Jones, Thomas M. 1995. Instrumental stakeholder theory: A synthesis of ethics and economics. Academy of Management Review 20: 404-37. [CrossRef]

Jones, Charles M., and Matthew Rhodes-Kropf. 2003. The Price of Diversifiable Risk in Venture Capital and Private Equity. Working Paper. New York: Columbia University.

Klassen, Robert D., and Curtis P. McLaughlin. 1996. The impact of environmental management on firm performance. Management Science 42: 1199-214. [CrossRef]

Kyaw, Khine. 2006. Inter-day dynamics of market variables on the LSE. Journal of International Finance and Economics 4: 83-94.

Langenmayr, Dominika, and Rebecca Lester. 2018. Taxation and corporate risk-taking. The Accounting Review 93: 237-66. [CrossRef]

Lintner, John. 1965. Security prices, risk and maximal gains from diversification. Journal of Finance 20: 587-615.

Malkiel, Burton G., and Yexiao Xu. 2002. Idiosyncratic Risk and Security Returns. Working Paper. Richardson: University of Texas at Dallas.

Mathew, Sudha., Ibrahim Salma, and Stuart Archbold. 2017. Corporate Governance and firm risk. Corporate Governance 18: 52-67. [CrossRef]

Melnyk, Steven A., Robert P. Sroufe, and Roger Calantone. 2003. Assessing the impact of environmental management systems on corporate and environmental performance. Journal of Operations Management 21: 329-51. [CrossRef]

Merton, Robert C. 1987. A simple model of capital market equilibrium with incomplete information. Journal of Finance 42: 483-510. [CrossRef]

Pathan, Shams. 2009. Strong boards, CEO power and bank risk-taking. Journal of Banking and Finance 33: 1340-50. [CrossRef]

Porter, Michael E. 1991. America's green strategy. Scientific American 264: 168. [CrossRef]

Porter, Michael E., and Mark R. Kramer. 2011. Creating shared value. Havard Business Review 89: 62-77.

Russo, Michael V., and Niran S. Harrison. 2005. Organizational design and environmental performance: Clues from the electronics industry. Academy of Management Journal 48: 582-93. [CrossRef] 
Sharfman, Mark P., and Chitru S. Fernando. 2008. Environmental risk Management and the cost of capital. Strategic Management Journal 29: 569-92. [CrossRef]

Wintoki, M. Babajide, James S. Linck, and Jeffry M. Netter. 2012. Endogeneity and the dynamics of internal corporate governance. Journal of Financial Economics 105: 581-606. [CrossRef]

(C) 2020 by the author. Licensee MDPI, Basel, Switzerland. This article is an open access article distributed under the terms and conditions of the Creative Commons Attribution (CC BY) license (http://creativecommons.org/licenses/by/4.0/). 